\title{
Intraoperative Frozen Section in Ovarian Neoplasms; A Tertiary Center Experience
}

\author{
Over Tümörlerinde İntraoperatif Frozen İncelemenin Tanısal Yeri; \\ Tek Merkez Deneyimi
}

\author{
Arbil AÇIKALIN ${ }^{1}$, Goncagül TORUN ${ }^{1}$, Emine BAĞIR ${ }^{1}$, Fatma BAYRAM ${ }^{1}$, Handan ZEREN ${ }^{1}$, Ümran GÜLEÇ², \\ Ahmet Barış GÜZEL ${ }^{2}$, Derya GÜMÜRDÜLÜ'1
}

Departments of 'Pathology and '2Obstetrics and Gynecology, Çukurova University, Faculty of Medicine, ADANA, TURKEY

\begin{abstract}
Objective: Frozen section is an accurate diagnostic tool with some unavoidable pitfalls in gynecologic tumors. We aimed to evaluate the diagnostic value of frozen section, and to detect the factors causing erroneous diagnosis in ovarian tumors.

Material and Method: Frozen section and paraffin section reports of 282 patients with ovarian neoplasms diagnosed between July 2006 and January 2013 in our institute were re-analyzed. Results were grouped into benign, borderline (for epithelial tumors) and malignant categories and compared between frozen section and paraffin section diagnosis, statistically.

Results: Overall diagnostic accuracy of frozen section was $96.5 \%$. Sensitivity of frozen section for benign, borderline and malignant tumors were $97.5 \%, 95.8 \%$, and $95.6 \%$ and the related specificities were $97.5 \%, 97.6 \%$, and $100 \%$, respectively. We found the lowest positive predictive value in borderline group $(79.3 \%)$, all of them with mucinous type epithelium. Second frequent discordant tumor type was immature teratoma.
\end{abstract}

Conclusion: Apart from the limitations of frozen section, pathologists should be aware of the pitfalls of technique and tumor types and tend to sample from the solid areas particularly in mucinous tumors and teratomas to avoid inappropriate surgery.

Key Words: Frozen section, Ovarian neoplasms, Quality control

\section{ÖZ}

Amaç: Jinekolojik tümörler için frozen kesit inceleme bazı tanısal tuzaklara karşın yeterli bir tanısal yöntemdir. Bu çalışmada, over tümörlerinde frozen incelemenin tanısal değerini ve tanısal yanlışlıkların nedenlerini tespit etmeyi amaçladık.

Gereç ve Yöntem: Kurumumuzda Haziran 2006 ve Ocak 2013 yılları arasında over tümörü nedeni ile frozen inceleme yapılmış olan toplam 282 hastaya ait sonuçlar yeniden değerlendirildi. Tanılar benign, borderline (epitelyal tümörler için) ve malign olmak üzere üç alt gruba ayrıldı. Frozen ve parafin kesit sonuçları istatistiksel olarak karşılaştırıldı.

Bulgular: Frozen incelemenin genel tanısal doğruluk oranı \%96,5 idi. Benign, borderline ve malign tümörler için frozen incelemenin duyarlığı sırasıyla \%97,5, \%95,8 ve \%95,6 idi. Özgüllük ise aynı sırayla, \%97,5, \%97,6 ve \%100 idi. En düşük pozitif prediktif değer borderline grubunda saptand $1 \% 79,3)$ ve hataya neden olan tüm olgular müsinöz tip epitelyal tümörler idi. Tanı uyumsuzluğu bulunan ikinci tümör grubu ise immatür teratom idi.

Sonuç: Frozen incelemenin kısıtlılıkları yanısıra, patoloğun frozen incelemenin teknik veya tümör tipi ile ilgili tuzaklarını bilmesi, özellikle müsinöz tümörler ve teratom olgularında solid görünen alanlardan örneklenmesi yetersiz veya gereksiz operasyon yapılmasını önlemek adına yararlı olacaktır.

Anahtar Sözcükler: Frozen inceleme, Over neoplazileri, Kalite kontrol

\section{INTRODUCTION}

Ovarian cancer is the most common lethal gynecologic cancer and the seventh most common cause of death from cancer in women ( $4.2 \%$ of deaths) worldwide $(1,2)$. Surgical management of ovarian neoplasms differs according to their subtypes. It is therefore important for the surgeon to determine the category of ovarian neoplasm preoperatively. Preoperative imaging methods such as ultrasonography or serologic evaluations have been used for this aim but they

(Turk Patoloji Derg 2014, 30:184-188)

Received : 28.03.2014 Accepted : 19.06.2014 are usually insufficient, especially in early stage cases. In this instance, intraoperative frozen section (FS) has been shown to be a highly sensitive and specific adjunctive method for the surgeon in management of appropriate operation. In present study, we documented the frozen and paraffin results of 282 cases, which were diagnosed in 6.5 years period in our institute. We also analyzed the concordance between FS and paraffin section (PS) and diagnostic accuracy of FS.

Correspondence: Arbil AÇIKALIN

Çukurova Üniversitesi Tip Fakültesi, Patoloji Anabilim Dalı,

01130, Sarıçam, ADANA, TURKEY

E-mail: arbilavci@yahoo.com Phone: +90 5324702120 


\section{MATERIALS and METHOD}

In this retrospective study, 282 ovarian neoplasms (42.8\% of all gynecologic FSs) with intraoperative FS reports diagnosed in our institute between July 2006 and January 2013 (6.5 years) were re-analyzed. Paraffin section diagnoses with non-tumoral ovarian lesions (massive ovarian edema, hemorrhagic necrosis, benign cysts, infections) were not included.

All fresh gross specimen were examined by a resident and a pathologist or particularly gynecopathologist, in terms of localization, size, color, content, heterogeneity, infiltration pattern of the tumor and condition of the ovarian capsule. One to four sections depending on the size and heterogeneity of the tumor were sampled in a cryostat and sections were stained by hematoxylin-eosin. Slides were evaluated and reported to the surgeon by the pathologist. Final PS diagnosis reported by an experienced gynecopathologist was accepted as accurate diagnose. In present study, we reanalyzed the FS and PS reports of cases. FS reports were categorized as benign, borderline (BL)(for epithelial tumors) and malignant. Benign and malignant groups included all epithelial, sex-cord stromal and germ cell tumors. BL group included only epithelial tumors. Results were compared for each category. Discordant cases were discussed depending on the clinical effects of the discordant FS diagnosis. Overall accuracy meant concordance between FS and PS results regardless of subtypes of the tumors. Sensitivity and specificity, positive and negative predictive values of FS were determined statistically. Statistical tests were based on benign/BL/malignant categorization.

\section{RESULTS}

The mean age of all cases was 44.9 (min: 12, max: 80) years. A total 282 ovarian neoplasms consisting of: 235 (83.3\%) epithelial tumors ( 85 benign, $24 \mathrm{BL}, 126$ malignant), 39 (13.8\%) sex-cord stromal tumors, and $8(2.8 \%)$ germ cell tumors were reviewed. All cases were diagnosed as benign, borderline (for epithelial tumors) or malignant on FS. Sub-categorization, in terms of histologic type, primary or metastasis was not possible in some cases of FS.

Overall diagnostic accuracy of FS was $96.5 \%$. Sensitivity, specificity, positive and negative predictive values of FS for benign, BL and malignant tumors are summarized in Table I.

Ten (3.5\%) out of 282 cases were discordant based on benign/BL/malignant sub-categorisation, which also caused over- or under-surgery (Table II). Histopathologic diagnoses of PSs in 10 discordant cases were as follows: 3 benign mucinous tumors, 1 mucinous $\mathrm{BL}$ tumor, 3 malignant mucinous tumors and 3 immature teratomas. Immature teratomas were diagnosed as mature teratomas in FS, due to the sampling error. Two cases, 28 and 37 years old ages were grade 1 immature teratoma with 16 and $21 \mathrm{~cm}$ diameter tumor, subsequently. Three solid areas sampled during FS

Table I: Statistical values of benign, borderline and malignant tumors

\begin{tabular}{|l|c|c|c|}
\hline Statistical result (\%) & Benign $^{\star}$ & Borderline $^{\star}$ & Malignant $^{\star}$ \\
\hline Sensitivity & 97.5 & 95.8 & 95.6 \\
\hline Specificity & 97.5 & 97.6 & 100 \\
\hline Positive predictive value & 96.7 & 79.3 & 100 \\
\hline Negative predictive value & 98.1 & 99.6 & 96 \\
\hline
\end{tabular}

* Benign and malignant tumors included epithelial, sex-cord stromal, germ cell tumors and metastasis, whereas borderline group included only epithelial tumors.

Table II: Comparison of frozen and paraffin diagnosis of all patients with respect to potential of malignancy

\begin{tabular}{|l|c|c|c|c|}
\hline \multicolumn{5}{|c|}{ Paraffin diagnosis } \\
\hline Frozen Diagnosis & Benign $^{*}$ & Borderline $^{*}$ & Malignant $^{*}$ & Total \\
\hline Benign & 117 & 1 & 3 & 121 \\
\hline Borderline & 3 & 23 & 3 & 29 \\
\hline Malignant & 0 & 0 & 132 & 282 \\
\hline Total & 120 & 24 & 138 & 132 \\
\hline
\end{tabular}

*Benign and malignant tumors included epithelial, sex-cord stromal, germ cell tumors and metastasis, whereas borderline group included only epithelial tumors. 
Table III: Discordant cases with respect to histopathologic subtypes

\begin{tabular}{|l|c|c|}
\hline Frozen diagnose & Paraffin diagnose & Number of cases \\
\hline \multirow{2}{*}{ Mucinous carcinoma $(2$ cases $)$} & Serous carcinoma (high grade) & 1 \\
\cline { 2 - 3 } & Malign mesothelioma metastasis & 1 \\
\hline Metastatic carcinoma & Serous carcinoma (high grade) & 2 \\
\hline Serous carcinoma, high grade & Clear cell carcinoma & 1 \\
\hline Malignant mesenchymal tumor & Small cell carcinoma, hypercalcemic type & 1 \\
\hline
\end{tabular}

did not include immature areas. On permanent sections, 3 slides for initial and 1 slide for the latter case included Grade 1 immature neuronal component among 20 paraffin samples plus 3 frozen samples (total 23 slides) for each. The third discordant case was 47 years old with a $10 \mathrm{~cm}$ diameter teratoma. Only 1 slide among 17 samples (14 paraffin +3 frozen) included Grade 2 immature neuronal area. Gross appearances of all these 3 cases were like a mature teratoma with chondroid, cystic, with keratinized material, and focal fleshy gray-yellow areas. Although focal, representative areas were detected mainly on samples from solid fields.

The other 7 discordant cases were all mucinous epithelial tumors. Three benign mucinous tumors were overdiagnosed as BL mucinous tumor on FS. One mucinous BL tumor was under-diagnosed as benign on FS. Three mucinous carcinomas were also under-diagnosed as BL.

In terms of histologic subtypes; benign serous tumors (56 cases), Brenner tumors (2 cases), serous BL tumors (18 cases), endometrioid adenocarcinomas ( 3 cases), metastasis (35 cases), fibroma/fibrotechomas ( 29 cases), granulosa cell tumors ( 9 cases), mature cystic teratomas (5 cases) were all correctly diagnosed in FS. There was some discordance with respect to histologic subtype among the malignant tumors (Table III). They were all reported to be malignant during FS, however histopathologic subtypes were different on PS report in 6 cases. Among these cases three were major mistakes, which caused under-/over-treatment due to FS diagnose. Two of them were 48 and 69 years old highgrade serous carcinoma cases, which were misdiagnosed as metastatic carcinoma during FS. These tumors were bilateral and showed capsular involvement grossly and with additive role of the freezing artefact microscopically, yielded us to think about metastasis. The third case ( 45 years old) was a surprise diagnosis with malignant mesothelioma metastasis, which was misdiagnosed as mucinous carcinoma on FS, and the patient was over-treated.

The only case with small cell carcinoma; hypercalcemic type was diagnosed as malignant mesenchymal tumor in FS. This was a rare tumor, which we could not recognize during FS. Other two misdiagnosed cases were one serous carcinoma and one clear cell carcinoma, which were subtyped as mucinous carcinoma and serous carcinoma on FS, respectively. These latter 3 cases were minor mistakes, which did not affect the surgical procedure.

There were 8 clear cell carcinoma cases ( 3 pure, 5 mixed with serous carcinoma) in the present study. Three cases (37.5\%) were misdiagnosed as serous ( 1 of the pure clear) or "malignant tumour; primary or metastatic carcinoma cannot be decided" ( 2 of the 5 mixed carcinomas) on FS.

Diagnosis of metastasize was principally based on clinical information, per-operative findings purposive for primary tumor (in case of unknown primary), bilaterality of the tumor, nodular infiltration pattern, involvement of ovarian capsule. Almost all metastatic tumors (94.3\%) were correlated with PS diagnoses except for 2 cases with malign mesothelioma and adenocarcinoma metastasis. Distribution of histopathologic subtypes of metastatic tumors was as follows: 18/35 (51.4\%) adenocarcinomas, $10 / 35(28.6 \%)$ ductal and 2/35 (5.7\%) lobular carcinomas of breast, $4 / 35$ (11.4\%) signet ring cell carcinoma, and 1/35 (2.9\%) malignant mesothelioma.

\section{DISCUSSION}

FS diagnosis of ovarian neoplasms is a stressful application for the pathologist considering the expectation of reproduction in young or middle aged women. Clinical, laboratory and radiologic information are important in FS evaluation as well as in all pathology area. However, ovarian FSs have an advantage of observation of the totally excised specimen mostly. This is very useful if the pathologist examines the gross specimen himself or herself with knowing the gross approaching to the ovarian tumors. Of course there are some tricks originating from FS technique or the tumor itself in which our hands are tied. Pathologist's role is to minimize the false positive and false negative rates by being aware of these handicaps and make the surgeon informed about them. In most institutes pathologists have been studying in particular sections. We sometimes see the disadvantages of this 
procedure especially in periods when the gynecopathologist is away. The pathologist of other sections may not be familiar with diagnostic clues and FS may become difficult. In spite of these disadvantages overall diagnostic accuracy of FS was reported to be reliable in large series ranging from $84.25 \%$ to $97.1 \%$, which was $96.5 \%$ in our study $(1,3-7)$. We think that attendance of the gynecopathologist to gross examination is a very important factor to increase the diagnostic accuracy of FS. Sensitivity and specificity of the FS in terms of benign and malignant tumors is also reported to be higher than $90 \%$ in the same studies.

Gross examination of the size, color, presence of solid/ cystic/papillary components, content of the cysts, necrosis, hemorrhage, capsule involvement, and infiltration pattern of the tumor (nodular, diffuse) will be helpful to reduce the number of tumors in the differential diagnosis. However, there are some tricks on microscopic evaluation. Freezing artifact usually dazzles the true cytologic features. Usubutun et al. have reported a false negative case of Krukenberg tumor diagnosed as fibrotechoma at FS $(8,9)$. Additional causative technical artifacts are massive hemorrhage and/or necrosis in the specimen. Samples should be selected apart from these changes as much as possible.

Ovarian BL tumors, especially mucinous types are the most stressful neoplasms in FS. Unsurprisingly, BL tumors show the lowest diagnostic values in the literature as well as in our study (sensitivity: 95.8\%, ppv: 79.3\%). In a pooled analysis of 1104 women with BL tumors showed an overall accuracy of $67.1 \%$, a sensitivity of $82.1 \%$ and ppv of $78.7 \%$ (10). These cases were either under-diagnosed or overdiagnosed. In present study majority of the discordant cases (7/10) were completely mucinous tumors. Three benign cases were over-diagnosed as BL tumor at FS. Two of them were 27 and 32 years old ages were not radically operated because of their fertility-sparing willing. However, third over-diagnosed patient at 48 years old, who was informed by the surgeon about the possible extent of the surgery up to the FS diagnoses, underwent total abdominal hysterectomy and bilateral salpingo-oopherectomy and appendectomy procedure. The patient was over-treated hence the PS report was mucinous cystadenoma.

Four patients were under-diagnosed in our study. One was up-graded from benign to $\mathrm{BL}$ and underwent a completion operation. Three patients were upgraded from BL to malignant. In our institute, we inform the surgeons to be cautious about the possibility of invasion focus in PS samples in BL mucinous tumors. In these situations, we prefer to report as "At least BL mucinous tumor" which was also recommended by Shih et al. (11).
The possible reasons for discordance between FS and PS in BL mucinous tumors are associated with characteristics of these tumors, such as larger sizes, and presence of benign, $\mathrm{BL}$ and malignant components in the same tumor, in contrast to serous tumors (12). The samples should be taken from the thickest and solid areas of the cystic neoplasms.

Immature teratoma was the second discordant tumor type with 3 cases in our study. The difficulty of this tumor has been stressed by some authors in the literature (8). In these cases, immature focuses were detected in paraffin section samples, which were not represented in FS as in present study. Being aware of possibility of immature areas should lead the pathologist to sample as more as possible from fleshy, gray colored areas.

Metastatic tumors especially the mucinous carcinomas may be challenging in FS if there is inadequate clinical information and communication with the surgeon. Additionally tumor size less than $10 \mathrm{~cm}$, bilaterality of the tumor, involvement of ovarian surface and nodular infiltration pattern are diagnostic clues for metastasize.

In conclusion, there are unavoidable limitations of FS of ovarian neoplasms originating from techniques, time and sampling narrowness, characteristics of tumor itself especially mucinous tumors and teratomas as present in this study. To avoid insufficient and unnecessary operations, preferably an experienced gynecopathologist should examine the gross specimen by himself or herself, be aware of the tricks and inform the surgeon to be cautious about the limitations of FS.

\section{REFERENCES}

1. Bige O, Demir A, Saygili U, Gode F, Uslu T, Koyuncuoglu M. Frozen section diagnoses of 578 ovarian tumors made by pathologists with and without expertise on gynecologic pathology. Gynecol Oncol. 2011;123:43-6.

2. Rosenthal AN, Menon U, Jacobs IJ. Screening for ovarian cancer. Clin Obstet Gynecol. 2006;49:433-47.

3. Yarandi F, Eftekhar Z, Izadi-Mood N, Shojaei H. Accuracy of intraoperative frozen section in the diagnosis of ovarian tumors. Aust N Z J Obstet Gynaecol. 2008;48:438-41.

4. Rakhshan A, Zham H, Kazempour M. Accuracy of frozen section diagnosis in ovarian masses: Experience at a tertiary oncology center. Archiv Gynecol Obstet. 2009;280:223-8.

5. Subbian A, Devi UK, Bafna UD. Accuracy rate of frozen section studies in ovarian cancers: A regional cancer institute experience. Indian J Cancer. 2013;50:302-5.

6. Toneva F, Wright H, Razvi K. Accuracy of frozen section in the diagnosis of ovarian tumours. J Obstetrics Gynaecol. 2012;32:47982. 
7. Ilvan S, Ramazanoglu R, Ulker Akyildiz E, Calay Z, Bese T, Oruc $\mathrm{N}$. The accuracy of frozen section (intraoperative consultation) in the diagnosis of ovarian masses. Gynecol Oncol. 2005;97:395-9.

8. Usubutun A, Altinok G, Kucukali T. The value of intraoperative consultation (frozen section) in the diagnosis of ovarian neoplasms. Acta Obstet Gynecol Scand. 1998;77:1013-6.

9. Young RH. From krukenberg to today: The ever present problems posed by metastatic tumors in the ovary: part I. Historical perspective, general principles, mucinous tumors including the krukenberg tumor. Adv Anat Pathol. 2006;13:205-27.
10. Song T, Choi CH, Kim HJ, Kim MK, Kim TJ, Lee JW, Bae DS Kim BG. Accuracy of frozen section diagnosis of borderline ovarian tumors. Gynecol Oncol. 2011;122:127-31.

11. Shih KK, Garg K, Soslow RA, Chi DS, Abu-Rustum NR, Barakat RR. Accuracy of frozen section diagnosis of ovarian borderline tumor. Gynecol Oncol. 2011;123:517-21.

12. Akrivos N, Thomakos N, Sotiropoulou M, Rodolakis A, Antsaklis A. Intraoperative consultation in ovarian pathology. Gynecologic Obstet Invest. 2010;70:193-9. 